\title{
KOMUNIKASI TRANSENDENTAL PENDERITA KANKER DI YAYASAN KANKER INDONESIA CABANG JAWA TIMUR
}

\author{
Mashfiyatul Asmaai
}

Universitas Islam Negeri Sunan Ampel Surabaya asmaai@gmail.com

\begin{tabular}{l}
\hline \hline Article Info \\
\hline \\
Article history: \\
Received 16 August 2018 \\
Accepted 15 September 2018 \\
Published 10 Oktober 2018 \\
\hline
\end{tabular}

Keyword:

Komunikasi, transendental, penderita kanker

\section{Abstract}

Penelitian ini membahas tentang tentang komunikasi transendental penderita kanker di Yayasan Kanker Indonesia Cabang jawa Timur. Segala hal yang dilakukan oleh penderita kanker dalam berkomunikasi dengan Tuhannya dikaji dalam penelitian ini. Penelitian ini menggunakan jenis penelitian kualitatif dengan pendekatan fenomenologi.

Hasil penelitian menunnjukkan bahwa penderita kanker menyampaikan pesan tentang kematian beserta kehidupan setelahnya. Pesan-pesan tersebut disampaikan penderita kanker menggunakan media yang memanfaatkan ibadah dan juga aktivitas sosial yang dilakukan sehari-hari.Model komunikasi komunikasi transendental penderita kanker terjadi secara vertikal yaitu langsung kepada Allah dan juga secara horizontal yaitu menyamping kepada sesama makhluk Allah dengan memperhatikan esensi pesan yang tujuannya tetap kepada Allah.

Berdasarkan hasil dari penelitian ini, peneliti menyarankan agar seluruh masyarakat mendukung pengobatan penderita kanker baik berupa materi maupun berupa dukungan spiritual. Karena segala bentuk perhatian dan dukungan sekecil apapun dapat berpengaruh bagi kekuatan mental dan kondisi psikologis penderita kanker yang nantinya akan berpengaruh terhadap perkembangan kesehatannya.

\section{Editorial Office:}

Program Studi Ilmu Komunikasi, Fakultas Dakwah dan Komunikasi, UIN Sunan Ampel Surabaya. Jl. Ahmad Yani 117 Surabaya, Jawa Timur, Indonesia.

Email: jurnalilkom@uinsby.ac.id 


\section{Pendahuluan}

Kesehatan merupakan anugerah Tuhan dan merupakan hak asasi manusia yang dijamin dalam undang-undang. Hal ini karena kesehatan adalah investasi dalam upaya membangun bangsa yang mempunyai peranan besar dalam meningkatkan derajat hidup manusia. Selain itu kesehatan juga berpengaruh langsung pada produktifitas manusia itu sendiri. Masalah kesehatan secara global telah mengalami perubahan besar dalam 2 dekade terakhir, salah satunya adalah pergeseran pola penyakit dari penyakit menular menjadi penyakit tidak menular

Saat ini penyakit tidak menular termasuk kanker menjadi masalah kesehatan utama di dunia. Berdasarkan data The International Agency for Research on Cancer (IARC) yang merupakan lembaga khusus kanker milik WHO tahun 2013 menunjukan bahwa insiden kejadian kanker meningkat dari 12,7 juta kasus pada tahun 2008 menjadi 14,1 juta kasus pada tahun 2012. Sedangkan jumlah kematian meningkat dari 7,6 juta orang pada tahun 2008 menjadi 8,2 juta pada tahun 2012. Menurut Kemenkes (2014) kanker penyebab kematian nomor 2 di dunia sebesar $13 \%$ setelah penyakit kardiovaskuler. Diperkirakan pada tahun 2030 insiden kanker mencapai 26 juta orang dan 17 juta diantaranya meninggal dunia. ${ }^{1}$

Di Indonesia sendiri berdasarkan data Riskesdas 2013 menunjukan bahwa prevalensi kanker mencapai 1,4 per 1.000 penduduk atau sekitar 330.000 orang.

\footnotetext{
${ }^{1}$ Rinkesdas (Riset kesehatan Dasar) Kemenkes RI tahun 2013
}

Sehingga diperkirakan ada 3.000.000 orang penduduk indonesia terkena kanker dan di Jawa Timur sendiri sebanyak 60.000 orang terkena kanker. Sedangkan di rumah singgah YKI Cabang Jatim tercatat selama tahun 2015 tercatat sebanyak 449 pasien kanker yang pernah tinggal disana.

Penyakit kanker dikenal sebagai penyakit amat ditakuti bukan hanya karena penyebab kematian tetapi juga karena menyebabkan penderitaan panjang bagi penderita, kecacatan dan membutuhkan biaya termahal untuk pengobatannya. Setiap manusia akan mengalami shock akibat mendengar kabar bahwa dirinya atau keluarganya terkena penyakit kanker. Karena itu setiap penderita kanker akan mengalami masalah atau penderitaan baik itu fisik, psikologis,sosial, kultural maupun spiritual.

Tingginya kasus kanker dan semakin banyaknya kasus baru dari kanker ini membuatnya menjadi salah satu penyakit yang menyebabkan kematian utama di seluruh dunia. Penyebabnya pada berbagai negara pun bervariasi, ada karena faktor perkapita yang rendah, lingkungan yang kumuh, polusi yang berlebihan, dan lain sebagainya. Yang kesemuanya itu bermuara kepada sebuah pernyataan, bahwa kanker merupakan sebuah momok yang menakutkan bagi masyarakat.

Tidak ada seorang pun di dunia ini yang ingin menderita suatu penyakit, apalagi sakit kanker. Lalu yang menjadi pertanyaan adalah bagaimana jika sudah terlanjur menderita sebuah penyakit ? apalagi penyakit tersebut merupakan salah 
satu penyakit berbahaya yang dapat menimbulkan penderitaan dan bahkan kematian. Meski di dunia ini tidak ada penyakit yang tidak bisa disembuhkan karena Tuhan pasti menurunkan penyakit sepasang dengan obatnya, manusia masih harus berusaha dengan melakukan banyak penelitian untuk mendapat obat yang benar-benar sesuai dengan penyakit tersebut. Dalam hadis Nabi Muhammad SAW, dari sahabat Abu Hurairah dijelaskan.

"Tidaklah Allah turunkan penyakit kecuali Allah turunkan pula obatnya". (HR. Bukhari).

Permasalahan yang muncul tidak semua orang yang sakit kanker mampu menerima kondisinya dengan ikhlas dan sabar. Banyak kejadian bahwa penderita kanker marah dan depresi terhadap kondisinya. Hal ini karena mereka kecewa terhadap proses kehidupan yang tidak berjalan sesuai dengan keinginannya sehingga menyebabkan dirinya marah terhadap Tuhan, menyalahkan keluarga atau lingkungan, menutup diri serta terkadang menolak untuk pengobatan dan jika dibiarkan dapat mencari jalan pintas dengan bunuh diri. Karena itu hanya keyakinannya pada Tuhan yang akan mampu menjadi penguat dirinya untuk tetap semangat menjalani kehidupan di dunia. Mengisinya dengan hal-hal baik dan meninggalkan segala yang menjadi larangan Tuhannya. Di sinilah letak pentingnya kedekatan antara manusia dengan Tuhan. Keyakinan penuh yang menimbulkan kedekatan yang mendalam

\footnotetext{
${ }^{2}$ Alqur'an dan Terjemahnya Surat Adz Dzaariyaat: 56.
}

antara manusia dan Tuhan akan mempermudah seseorang yang menderita penyakit dalam menjalani kehidupannya yang berbeda dengan manusia normal lainnya.

Pada dasarnya, kekuatan hati manusia itu terletak pada kedekatannya dengan Tuhan. Kedekatan itu dapat dicapai dengan cara beribadah. Ibadah merupakan salah satu aktivitas rohani yang bertujuan mendekatkan diri dengan Tuhan. Keberadaan manusia dunia ini tiada lain hanyalah untuk beribadah kepada Allah. Makna ibadah yang dimaksud tentu saja adalah pengertian ibadah yang benar-benar mendekatkan diri kepada Tuhan, bukan berarti hanya shalat, puasa, zakat, dan haji saja, tetapi ibadah dalam setiap aspek kehidupan manusia, baik itu Maghdah maupun Muamalah. Allah Subhannahu wa Ta'ala berfirman : "Dan Aku tidak menciptakan jin dan manusia melainkan supaya mereka menyembah-Ku. ${ }^{2}$

Ibadah juga memiliki kaitan yang cukup erat dengan komunikasi. Komunikasi sangat penting peranannya bagi kehidupan sosial, budaya, politik dan pendidikan, karena komunikasi merupakan proses dinamik transaksional yang mempengaruhi perilaku, yang mana sumber dan penerimaannya sengaja menyandi (tocode) perilaku mereka untuk menghasilkan pesan yang mereka salurkan melalui suatu saluran (Channel) guna merangsang atau memperoleh sikap atau perilaku tertentu sebagai konsekuensi dari hubungan sosial. $^{3}$ Konsekuensi lain manusia selain menjadi mahkluk sosial

\footnotetext{
${ }^{3}$ Deddy mulyana dkk, Komunikasi Antar Pribadi (Bandung: PT Remaja Rosda Karya,1990) hlm. 15
} 
adalah komunikasi, dimana menurut Carl

I. Hovland komunikasi adalah proses dimana seseorang menyampaikan perangsang yang berbentuk lambanglambang dalam rangka untuk merubah perilaku seseorang atau orang lain. ${ }^{4}$ Ibadah manusia dengan Tuhan juga merupakan salah satu bentuk komunikasi. Komunikasi yang melibatkan manusia dengan Tuhannya itulah yang disebut komunikasi transcendental. ${ }^{5}$

Salah satu fenomena menarik yang berkenaan dengan penyakit kanker di Jawa Timur adalah adanya Yayasan Kanker Indonesia (YKI) Cabang Jawa Timur. YKI Cabang Jawa Timur yang mempunyai rumah singgah sebagai tempat hunian sementara bagi pasien yang berasal dari luar kota dan luar pulau yang sedang menjalani pengobatan kanker di Surabaya. Kehidupan di rumah singgah sangat menarik karena dihuni oleh para penderita kanker dari berbagai daerah dengan kondisi sosial, ekonomi dan pendidikan serta usia yang berbeda pula. Sehingga pemahaman mereka terhadap penyakitnya dan pengobatan penyakitnya sangat beragam. Salah satu bentuk kegiatan untuk menguatkan sisi spiritual pasien adalah pengajian rutin bagi pasien yang beragama Islam setiap hari rabu. Kegiatan ini sudah dilaksanakan sejak tahun 2013 sampai sekarang.

Penelitian ini dimaksudkan untuk mengetahui bagaimana penderita kanker melakukan komunikasi dengan Tuhan

\footnotetext{
${ }^{4}$ Yoyon, mudjiono, Ilmu Komunikasi (Surabaya: Jaudar press, 2013).

5 Deddy Mulyana, Nuansa-Nuansa Komunikasi; Meneropong Politik dan Budaya Komunikasi
}

yang memberikan sakit kanker pada dirinya. Sehingga dapat menjadi motivasi untuk masyarakat supaya lebih mendekatkan diri kepada tuhan sebagai rasa syukur terhadap anugerah berupa kesehatan yang tidak dimiliki oleh penderita kanker.

\section{Kajian Pustaka}

\section{Komunikasi Intrapersonal dan Kondisi Psikologis Penderita Kanker}

Komunikasi intrapersonal adalah komunikasi yang terjadi dengan diri sendiri. Ini merupakan dialog internal dan bahkan dapat terjadi saat bersama dengan orang lain sekalipun. Pada komunikasi intrapersonal, individu mempelajari peran kognisi dalam perilaku kesehariannya. Dalam konteks ini biasanya dilakukan berulang- ulang daripada dengan komunikasi lainnya. Uniknya lagi, komunikasi intrapersonal memungkinkan individu untuk membayangkan, melamun, mempersepsikan dan memecahkan masalah dalam pikirannya. ${ }^{6}$

Komunikasi intrapersonal dapat menjadi pemicu individu untuk melakukan bentuk komunikasi yang lainnya. Pengetahuan mengenai diri sendiri melalui proses-proses psikologis seperti persepsi dan kesadaran (awareness) terjadi saat berlangsungnya komunikasi intrapribadi.

Menurut Rakhmat, komunikasi intrapersonal adalah proses pengolahan informasi. Begitu juga yang dialami oleh penderita kanker. Proses ini melewati

Masyarakat Kontemporer (Remaja Rosdakarya: Bandung, 1990), hlm. 49.

${ }^{6}$ Richard West and Lynn. H. Turner, Pengantar Teori Komunikasi, (Jakarta: Salemba Humanika, 2009), hlm. 34 
empat tahap: sensasi, persepsi, memori, dan berpikir.

Sedangkan individu yang baru saja didiagnosa penyakit kanker menunjukkan beragam respon psikologis dan emosional. Beberapa orang melihat kanker sebagai kalimat kematian dan pengalaman mengalahkan proses berduka, sering kali menyerah. Beberapa orang yang lain dapat merasa bersalah karena meyakini kanker sebagai hukuman atas perilaku di masa lalu, seperti merokok, kebiasaan makan tidak sehat, atau menunda diagnosis. Individu dapat mengalami kemarahan, terutama jika merasa bahwa dirinya sudah mempraktikkan gaya hidup sehat. Ketakutan merupakan hal yang umum terjadi, takut akan efek terapi dan bahkan takut dengan kematian. Selain itu beberapa orang merasa terisolasi karena stigma kanker dan keyakinan lama bahwa akan terjadi penularan. ${ }^{7}$

Penderita kanker bukan saja mengalami sakit fisik, melainkan juga perubahan pada psikologi mereka. Berbagai perasaan tidak nyaman akan hadir pada pasien kanker. Rasa takut, sedih, dan khawatir karena sakit yang mereka derita. Terkadang perasaanperasaan tersebut terus berkembang dan megubah diri penderita kanker menjadi orang yang pesimis, mudah putus sa, dan tidak lagi memiliki semangat dalam hidupnya. Tidak ada gunanya mengobati badan tanpa mengobati pikiranya. Pemikiran ini sangat mengena, terutama

7 Priscilla LeMone, Buku Ajar Keperawatan Medikal Beda (Jakarta: Volume 1 Edisi 5 EGC, 2015), hlm. 439 pada para penderita penyakit berat, termasuk di dalamnya penderita kanker. Badan yang sakit akan mempengaruhi pikiran dan sebaliknya demikian. Badan yang sehat juga akan berpengaruh menyehatkan pikiran dan juga sebaliknya. ${ }^{8}$ Ilmu pengetahuan juga membuktikan bahwa kondisi emosional individu akan memengaruhi tingkat kekebalan tubuh manusia. Orang yang berada pada tingkat emosional yang rapuh akan lebih cepat tertularkan penyakit karena tingkat kekebalan tubuhnya menurun akibat emosi yang buruk. Kondisi emosi yang positif dan penuh pengharapan akan meningkatkan daya tahan tubuh, sedangkan sikap negatif, takut, dan pasrah akan menurunkan kekebalan tubuh. Perubahan kondisi emosi ini akan diteruskan di dalam rangkaian proses biokimia di dalam tubuh. Hal yang sebaliknya juga terjadi, yaitu perbaikan tingkat emosional dan pikiran. Pengobatan yang menyeluruh (holistik) merupakan cara penyembuhan yang perlu diupayakan jika keduanya diperbaiki dalam waktu yang bersamaan. ${ }^{9}$

Penderita kanker harus dapat mengendalikan pikiranya. Pikiran manusia dapat menjadi teman, tetapi sebaliknya dapat menjadi musuh bagi dirinya. Cara pengendalian ini umumnya dapat dilakukan dengan meditasi, berdo'a, berbicara dengan diri sendiri melalui visualisasi, dan cara-cara self healing lainya. Yoga atau cara meditasi lain

8 Aqila Smart, Kanker Organ Reroduksi (Jogjakarta: A+Plus Books, 2013), hlm. 32.

${ }^{9}$ Aqila Smart, Kanker Organ Reroduksi. , hlm. 33 
terbukti dapat membantu manusia untuk mengosongkan pikiran dan seterusnya membangun sikap mental yang baik terhadap tantangan fisik yang ada. Salah satu tehnik yang dinamakan "kekuatan dari keinginan", yaitu secara mental individu melatih dirinya dan mentalnya untuk percaya seyakin-yakinya bahwa ia dapat menghadapi tantangan ini. Teknik ini terbukti dapat membantu penyembuhan berbagai macam penyakit. Teknik-teknik pengendalian pikiran banyak tersedia dan dapat dipelajari dan terbukti sangat membantu penyembuhan berbagai penyakit. ${ }^{10}$

\section{Pengobatan penyakit Kanker}

Menurut Smart, pengobatan untuk mengatasi penyakit kanker biasanya berupa pengobatan medis dengan farmakologi dan pembedahan yang meliputi;

Pertama, Kemoterapi, prinsip pengobatan kanker dengan kemoterapi adalah dengan meracuni atau membunuh sel-sel kanker, mengontrol pertumbuhan sel kanker, dan menghentikan pertumbuhanya. Dengan demikian, diharapkan sel-sel kanker tidak menyebar. Selain itu, juga digunakan untuk mengurangi gejala-gejala yang disebabkan oleh kanker. Pengobatan dengan cara kemoterapi ini biasanya menjadi pilihan pertama dalam menangani kanker. Pengobatan ini bersifat sistematik sehingga berbeda dengan radiasi atau pengobatan lainnya. Perlu diketahui bahwa radiasi atau pembedahan hanya bersifat setempat,

\footnotetext{
${ }^{10}$ Aqila Smart, Kanker Organ Reroduksi. , hlm.
} 36. sedangkan kemoterapi dapat menjangkau sel-sel kanker yang mungkin sudah menjalar dan menyebar ke bagian tubuh yang lain.

Kemoterapi digunakan secara berbeda-beda pada setiap penderita kanker. Terkadang kemoterapi digunakan sebagai pengobatan utama, namun pada kasus lain dilakukan sebelum atau setelah operasi dan radiasi, tingkat keberhasilannya pun bervariasi, tergantung jenis kankernya.

\section{Komunikasi Transendental}

Ada banyak persepsi mengenai definisi komunikasi transendental. Mulai dari perspektif filsafat Islam, perspektif sosiologi, perspektif psikologi atau bahkan perspektif antropologi. Dari semua definisi dari berbagai perspektif tersebut, bisa disimpulkan bahwa komunikasi transendental memiliki definisi yaitu komunikasi yang berlangsung di dalam diri, dengan sesuatu 'di luar diri' yang disadari keberadaannya oleh individu karena adanya kesadaran tentang esensi di balik eksistensi. ${ }^{34}$ Sedangkan Sidharta berpandapat dalam bukunya yang berjudul Transendental Quotiont;

"Secara harfiah konsep transendental berarti sesuatu teramat penting, hal-hal yang di luar kemampuan manusia biasa untuk memahaminya. Kecerdasan transendental merupakan kemampuan umat manusia secara individu dan kolektif (berjamaah) untuk memahami dan malaksanakn aturan Tuhan untuk 
mendapat kesuksesan dan kebahagiaan di dunia dan akhirat". ${ }^{11}$

Sidharta mengungkapkan bahwa ketika seseorang berbicara tentang transendental, maka sama saja dengan berbicara tentang dimensi keTuhanan. Yang berlaku adalah aturan dan ketentuan Tuhan, bukan lagi sekedar nilai-nilai universal tentang Hak Asasi manusia (HAM). Dalam kecerdasan transendental, nilai-nilai, norma dan etika kemanusiaan dibawa lagi ke dimensi yang lebih tinggi untuk mendapatkan pengesahan benar atau salah. Karena aturan dan ketentuan Tuhan, maka itulah kebenaran yang berlaku di alam semesta. ${ }^{12}$

Hubungan komunikasi manusia dengan Tuhan dalam Islam ditempuh melalui ibadah, seperti shalat, dzikir, do'a serta ibadah-ibadah lain yang tujuannya mendekatkan diri kepada Tuhan ataupun memiliki permohonan-permohonan tertentu yang ingin agar dikabulkan oleh Allah SWT. ${ }^{13}$ Melalui ibadah, manusia dapat melakukan komunikasi dengan Tuhan tanpa penghalang. Manusia dapat menyampaikan segala apa yang ingin dicurahkan kepada Tuhan dalam melakukan ibadah. Jika diibaratkan pada komunikasi antar manusia, komunikasi transendental terjadi dengan penyampaian pesan berupa informasi ataupun permintaan-permintaan bahkan keluhan

11 Syahmuharnis dan Harry Sidharta, $T Q$ Transcendental Quotient (Jakarta Selatan: Republika, 2006), hlm. 54.

12 Syahmuharnis dan Harry Sidharta, $T Q$ Transcendental...55.

${ }_{13}$ Deddy Mulyana, Nuansa-Nuansa Komunikasi, hlm. 49

${ }^{14}$ Aep Kusnawan Ash- Shiddiq, Do 'a-Do'a Sukses for Teens (Bandung: Mizan, 2007), hlm. 34-35. yang disampaikan manusia kepada Tuhan. Komunikasi transendental bisa dibentuk dalam suasana dekat, akrab dan mesra ditentukan oleh kondisi fisik dan psikis, lingkungan, waktu dan tempat saat berkomunikasi dengan Tuhan. ${ }^{14}$ Menurut jumhur ulama': "Ibadah adalah nama yang mencakup segala sesuatu yang disukai Allah dan yang diridlai- Nya, baik berupa perkataan maupun perbuatan, baik terangterangan maupun diam- diam."15

Model komunikasi transendental dimaksudkan sebagai sebuah model yang diberlakukan dalam struktur simbol dan aturan proses komunikasi dalam AlQur'an. Proses perjalanan kata-kata atau simbol sebagai pesan komunikasi memiliki model tersendiri dalam komunikasi transcendental.

Ada tiga model komunikasi yang paling mendekati dalam proses komunikasi transendental, yaitu Model S-R, Model Aristoteles dan Model Lasswell. ${ }^{16}$ Deddy Mulyana menjelaskan secara terperinci mengenai tiga model tersebut, yaitu; ${ }^{17}$

Model Stimulus-Respons (S-R) adalah model komunikasi paling dasar. Model ini dipengaruhi oleh disiplin psikologi, khususnya yang beraliran behavioristik, dan menunjukkan komunikasi sebagai sebuah proses "aksireaksi" yang sangat sederhana. Jadi model S-R mengasumsikan bahwa kata-kata

${ }^{15}$ H. E Hassan Saleh, (ed.), Kajian Fiqh Nabawi \& Fiqh Kontemporer, (Jakarta : PT Raja Grafindo Persada, 2008), hlm. 3-5

16 Wahidah Suryani, Komunikasi Transendental Manusia-Tuhan, , hlm. 160

17 Deddy Mulyana, Ilmu Komunikasi (Bandung: Remjaja Rosdakarya, 2001), hlm. 132-136 
verbal misalnya ayat-ayat dalam al-Qur'an dan isyarat-isyarat alam akan merangsang seorang manusia untuk melakukan tindakan atau respons tertentu. Respons yang muncul seperti melaksanakan dan menjauhi apa yang dilarang dan diperintahkan, respons berupa rasa takjub, terpana bahkan terharu melihat berbagai keagungan ciptaan Allah. Proses ini dapat bersifat timbal balik dan mempunyai banyak efek. Setiap efek dapat mengubah tindakan komunikasi berikutnya.

Model Aristoteles adalah model komunikasi paling klasik, yang sering juga disebut model retoris. Aristoteles mengemukakan tiga unsur dasar proses komunikasi ini, yaitu pembicara, pesan, dan pendengar. Dalam komunikasi transendental, manusia sebagai hamba terkadang menjadi pembicara atau komunikator, yang secara sadar melakukan zikir sesuai dengan petunjuk d zikir yang telah dipelajarinya atau do'a-do'a yang dianggap bagus sehingga bisa dikabulkan oleh Allah. Zikir atau do'a itu tidak hanya disampaikan begitu saja, tapi melalui berbagai strategi untuk mendekatkan diri sedekat mungkin dengan Allah yakni berusaha untuk khusyuk.

Model komunikasi Lasswell berupa ungkapan verbal, yakni: Who says what, in which channel, to whom, with what effect. Model Lasswell sering diterapkan dalam komunikasi massa, namun juga bisa sejalan bila dipakai sebagai model komunikasi transendental. Unsur sumber who adalah partisipan komunikasi transendental sendiri yakni Allah dan Manusia. Unsur pesan (says what) adalah apa yang dikatakan Allah melalui ayat-ayat al- Qur'an dan ayat- ayat yang disaksikan lewat ciptaan Allah.

Juga pesan yang diucapkan manusia saat shalat, berzikir, berdo'a atau bentuk ibadah lainnya. Unsur saluran (in which channel), bila pesan dari Allah maka alQur'an bisa jadi saluran yang menyampaikan pesan-pesan Allah dan bila pesan dari manusia maka salurannya adalah sesuatu yang bersifat abstrak yang ada dalam diri setiap individu, yang hanya bisa dirasakan atau diketahui oleh manusia yang melakukan proses komunikasi transendental dengan Allah. Unsur penerima (To whom) sama dengan sumber, di mana Allah dan manusia berfungsi timbal-balik sebagai sumber dan penerima. Sementara unsur pengaruh (with what effect) jelas berhubungan dengan akibat yang ditimbulkan pesan komunikasi. Bagi manusia efek yang dirasakan adalah do'a yang terkabul atau kesenangan baru, sedangkan pesan Allah bisa melahirkan kepatuhan dan ketundukan manusia dalam melaksanakan perintah dan menjahui larangan.

Pendapat lain mengenai model komunikasi transendental disampaikan oleh Prof. Nina Winangsih. Proses komunikasi transendental yang berasal dari perpaduan proses IQ, EQ dan SQ sehingga menghasilkan keberhasilan komunikasi spiritual dan transendental. Keselarasan IQ, EQ dan SQ dapat mewujudkan proses komunikasi yang 
efektif, sesuai dengan kehendak Allah SWT, manusia dan alam ${ }^{18}$

Kecerdasan ini digunakan untuk menyelesaikan masalah makna dan nilai, yaitu kecerdasan untuk menempatkan perilaku dan hidup dalam konteks makna yang lebih luas dan kaya, kecerdasan untuk menilai bahwa tindakan atau jalan hidup seseorang lebih bermakna dibanding dengan orang lain.

\section{Metode Penelitian}

Penelitian ini menggunakan pendekatan fenomenologi, dimana peneliti melakukan pengamatan dan berinteraksi dengan penderita kanker. Peneliti berusaha memahami bahasa dan tafsiran penderita kanker atas dunianya. Peneliti akan berusaha mengungkapkan dan memahami realitas penelitian berdasarkan perspektif penderita kanker. Sebagaimana tradisi studi fenomenologi yang umumnya menjelaskan makna pengalaman hidup sejumlah orangtentang suatu konsep atau gejala, penelitian ini juga berupaya mendeskripsikan pengalamanpengalaman hidup penderita kanker, khususnya pengalaman dalam komunikasi transendental. Peneliti berusaha masuk kedalam dunia konseptual para penderita kanker, sehingga peneliti mengerti apa dan bagaimana suatu pengertian yang dikembangkan oleh penderita kanker dalam memaknai segala proses komunikasi transendental yang terjadi.

Penelitian ini juga menggunakan jenis penelitian kualitatif dengan berdasarkan pada : data yang berwujud kata - kata dari penderita kanker maupun dari orang-orang yang hidup di sekitarnya dan bukan rangkaian angka. Sehingga yang menjadi tujuan dari penelitian kualitatif ini adalah ingin menggambarkan data empirik berupa komunikasi transendental penderita kanker secara mendalam, rinci dan tuntas.

\section{Hasil dan Pembahasan}

komunikasi transendental penderita kanker di Yayasan Kanker Indonesia Cabang jawa Timur

1. Kehidupan Setelah Kematian Menjadi Hal Utama dalam Pesan Komunikasi Transendental Penderita Kanker

Kematian memang tidak selalu disebabkan oleh penyakit, namun saat individu mengalami sakit apalagi sakit parah, maka kemungkinan menuju kematian lebih besar dari pada orang dengan keadaan normal dan sehat. Semua orang menginginkan kehidupan yang damai dan sejahtera, baik itu kehidupan di dunia maupun kehidupan di akhirat setelah kematian.

Kehidupan setelah kematian ditentukan oleh kehidupan individu di dunia. Dalam Al-Qur'an, Allah sudah menjanjikan surga bagi individu yang melakukan segala perintah Allah dan menjauhi larangan-NYA. Sebaliknya, Allah telah menyediakan neraka bagi individu yang melakukan perbuatan yang tidak disukai oleh Allah selama hidup di dunia.

Pesan-pesan yang disampaikan penderita kanker kepada Allah juga berupa keinginan menuju kesembuhan.
18 Nina Winangsih Syam, Komunikasi Transendental. , hlm. Xviii 
Bukan hanya kesembuhan untuk dirinya semata. Namun juga kesembuhan untuk teman-teman sesama penderita kanker. Tidak berhenti sampai di situ, penderita kanker meminta agar tidak ada lagi orang yang terkena kannker di dunia ini. Intinya penderita kanker ingin agar penyakitkanker hilang dari dunia ini. Penyakit yang meresahkan banyak orang, menghabiskan waktu, menghabiskan tenaga dan menghabiskan banyak biaya.

Penelitian ini menemukan bahwa penderita kanker menyadari bahwa dirinya diberi kesempatan oleh Allah untuk memperbaiki diri. Selain itu penderita kanker memiliki pikiran, jika di dunia sudah diberi sakit yang berarti kesulitan, maka Allah akan memberikan kenikmatan di akhirat nanti. Dengan pemikiran yang positif tersebut, penderita kanker bisa lebih tenang dalam menjalani kesehariannya dengan penyakitnya.

2. Penderita Kanker Berkomunikasi dengan Tuhan Melalui Ibadah dan Aktivitas Sehari-Hari

Penggunaan media dalam komunikasi transendental bergantung pada maksud dan tujuannya. Dalam penelitian ini penderita kanker menggunakan ibadah rutinan sebagai media komunikasi transendental. Seperti shalat, membaca Al-Qur'an, puasa, berdzikir dan berdo'a, bahkan bersedekah.

Shalat yang dilakukan oleh penderita kanker mengandung simbol dan makna tersendiri. Jika untuk berkomunikasi dengan orang penting saja penderita kanker menggunakan tata krama yang bagus, apalagi untuk berkomunikasi dengan Tuhan Yang Maha Kuasa. Penderita kanker melakukan shalat dengan etika yang sangat baik, salah satunya dengan khusyu' dalam berdo'a dan memaknai tanda-tanda yang ada dalam shalat mulai dari gerakan hingga bacaan shalat itu sendiri.

Puasa dan silaturahim yang dilakukan oleh penderita kanker juga merupakan implikasi dari rasa syukur penderita kanker kepada Tuhan. Saat dirinya benar-benar dalam kondisi yang tidak memungkinkan untuk berpuasa dan melakukan banyak ativitas, di situlah penderita kanker bisa merasakan nikmatnya bisa menjalnkan aktivitas sehari-hari secara normal. Jadi ketika penderita kanker merasa dirinya sudah lebih kuat untuk beraktivitas, rasa syukur untuk menjaga kesehatan dan menampakkan tidak adanya rasa kecewa terhadap Tuhan dilakukan dengan puasa dan menjaga silaturahim pada sesama.

Penelitian ini menemukan bahwa penderita kanker menyampaikan maksud dan tujuannya kepada Allah menggunakan barbagai macam media. Salah satunya yaitu media yang pelaksanaannya tergantung pada pribadi yang bersangkutan, seperti shalat, puasa, berdzikir dan berdo'a. Penderita kanker merencanakan, memilih dan melaksanaknnya sendiri sesuka hati sesuai dengan kondisi 
pribadi masing-masing. Ada juga penggunaan media yang pelaksanaannya membutuhkan orang lain sebagai sasarannya, seperti silaturahim dan sedekah. Esensi dari silaturahim dan sedekah yang dilakukan penderita kanker tetap dalam nuansa komunikasi transendental, yaitu tertuju kepada Allah SWT, baik sebagai rasa syukur ataupun ada permohonan-permohonan tertentu.

3. Komunikasi Transendental Penderita Kanker Terjadi Secara Vertikal dan Horizontal

Model komuniasi transendental penderita kanker bukan hanya terjadi secara vertikal ke atas, namun juga terjadi secara horizontal ke samping. Maksud dari model komunikasi secara vertikal yaitu komunikasi transendental yang dilakukan oleh individu langsung kepada Allah melalui ibadah-ibadah yang dilakukannya sendiri. Jadi semua pesan langsung tertuju kepada Allah. Sedangkan untuk model komunikasi transendental secara horizontal yaitu komunikasi transendental yang berhubungan dengan individu lain atau lingkungan. Jadi meskipun komunikasi transendental berlangsung secara menyamping kepada sesama makhluk Allah, esensi dari komunikasi tersebut tetap tertuju kepada Allah. Karena komunikasi yang dilakukan secara menyamping hanyalah jalan agar maksud dan tujuannya tetap tersampaikan kepada Allah.
Komuniasi transendental dari perspektif interaksi simbolik adalah suatu aktivitas yang merupakan ciri khas manusia, yakni pertukaran simbol yang diberi makna. Penganut interaksionisme simbolik berpandangan bahwa perilaku manusia pada dasarnya adalah produk dari interpretasi mereka atas dunia sekelilingnya. Perspektif interaksi simbolik berusaha memahami perilaku manusia dari sudut pandang subyek. Perspektif ini memberi saran agar perilaku manusia dilihat sebagai proses yang memungkinkan manusia untuk membentuk perilaku mereka dengan mempertimbangkan ekspektasi orang lain, situasi, obyek dan bahkan diri mereka sendiri yang menentukan perilaku mereka.

Teori interaksi simbolik berpendapat bahwa kehidupan sosial dan transendental pada dasarnya adalah interaksi manusia yang menggunakan simbol-simbol, mereka tertarik pada cara manusia menggunakan simbol- simbol yang merepresentasikan apa yang mereka maksudkan untuk berkomunikasi dengan sesamanya maupun Tuhannya. Komunikasi dalam perspektif interaksi simbolik digambarkan sebagai pembentukan makna penafsiran atas pesan atau perilaku orang lain oleh peserta komunikasi. Interaksi simbolik memberikan banyak penekanan pada individu yang aktif dan kreatif dalam proses pertukaran simbolnya.

Penelitian ini menemukan bahwa penderita kanker yang berinteraksi dengan Allah dan lingkungannya juga menggunakan simbol-simbol sebagai representasi dari mkasud dan tujuan mereka. Apapun yang dilakukan oleh 
penderita kanker, memiliki tujuan tersendiri yang tidak semua orang bisa memahaminya. Simbol-simbol yang dipilih oleh penderita kanekr dalam melakukan komunikasi transendental berdasarkan pengetahuan dan pemahaman yang dimiliki oleh penderita kanker mengenai penyakitnya dan kehidupannya sendiri.

Secara umum, teori interaksionise simbolik didasarkan pada premis-premis sebagai berikut;

Pertama, Individu merespon suatu situasi simbolik, mereka merespon lingkungan termasuk obyek fisik (benda) dan objek sosial (perilaku manusia) berdasarkan media yang dikandung komponen-komponen lingkungan tersebut bagi mereka.

Penderita kanker merespon dengan baik dukungan dari keluarga dan lingkungan untuk mencari pengobatan terbaik, sehingga menimbulkan semangat untuk menjalani pengobatan demi kesembuhan total. Begitu juga dengan kegiatan-kegiatan yang dilakukan oleh para relawan.

Respon yang sangat baik diberikan oleh penderita kanker yang membuat hormon kebahagiaan menjadi bertambah, sehingga berpengaruh bagi kondisi psikis dan fisik penderita kanker. Selain itu penderita kanker memberikan respon positif kepada Allah dengan bersyukur, menjalankan segala perintah Allah dan menjauhi larangan-NYA atas kebaikan Allah memberikan mereka keluarga dan lingkungan yang setia menemani dan mendukun kesembuhan mereka.
Kedua, Makna adalah produk interaksi sosial, karena itu makna tidak melihat pada obyek, melainkan dinegosiasikan melalui penggunaan bahasa, negosiasi itu dimungkinkan karena manusia mampu mewarnai segala sesuatu bukan hanya objek fisik, tindakan atau peristiwa (bahkan tanpa kehadiran objek fisik, tindakan atau peristiwa itu) namun juga gagasan yang abstrak.

Pemberian makna penderita kanker terhadap dukungan dari keluarga dan lingkungan yaitu kasih sayang yang besar dari keluarga untuk diri penderita kanker. Kalau saja kasih sayang itu hanya seujung kuku, maka kemungkinan besar keluarganya akan tidak peduli dan meninggalka penderita kanker. Makna bahwa Allah sangat sayang dan tak pernah meninggalkan hamba-NYA juga ada dalam pikiran dan hati penderita kanker. Allah memberikan penyakit ganas berupa kanker dalam tubuh mereka dengan memberikan pendamping yang super perhatian dan mendukung mereka.

Hal-hal yang dilakukan oleh penderita kanker memiliki makna tersendiri bagi dirinya. Seperti halnya melakukan ibadah dengan makna penghambaan kepada Allah. Melakukan apa yang disukai oleh Allah dan menjauhi apa yang dimurkai Allah dimaknai penderita kanker sebagai wujud pengabdiannya kepada Allah. Berusaha lulus dari ujian yang diberikan oleh Allah berupa penyakit kanker. Perbuatanperbuatan baik dalam pergaulannya dengan sesama makhluk Allah yang dilakukan oleh penderita kanker dimaknai sebagai rasa syukur atas segala nikmat 
yang diberikan Allah, sebagai wujud keridloan menerima penyakit kanker dalam kehidupannya.

$$
\text { Ketiga, }
$$
Makna

yang

diinterpretasikan individu dapat berubah dari waktu ke waktu, sejalan dengan perubahan situasi yang ditemukan dalam interaksi sosial, perubahan interpretasi dimungkinkan karena individu dapat melakukan proses mental, yakni berkomunikasi dengan dirinya sendiri.

Penderita kanker tidak serta merta secara langsung memiliki makna positif terhadap penyakit kanker. Awal dinyatakan mengidap penyakit kanker juga sempat membuat penderita kanker menjadi down. Namun dengan berjalannya waktu, penderita kanker mendapat motivasimotivasi dari dokter, keluarga dan lingkungan, sehingga makna negatif mengenai pemahaman penyakit kanker bisa sedikit demi sedikit berbelok pada arah yang positif.

Simbol-simbol yang digunakan oleh penderita kanker memiliki dalam melakukan komunikasi transendental memiliki makna sendiri sesuai dengan persepsi masing-masing. Seperti RR yang ikut membantu merawat jenazah penderita kanker yang sudah meninggal. RR memaknai hal tersebut sebagai simbol kesiapannya untuk menghadapi kematian yang bisa kapan saja datang kepadanya.

Kemudian sedekah subuh yang selalu dilakukan oleh NH bersama istrinya. $\mathrm{NH}$ memiliki makna simbol rasa syukur yang begitu besar dalam sedekah yang dilakukannya. Begitu juga SA memaknai dzikir yang rutin dilakukan setiap hari sebagai simbol dari harapan-harapan yang diinginkannya.

\section{Kesimpulan}

Hasil penelitian ini menyimpulkan bahwa komunikasi transendental penderita kanker di Yayasan Kanker Indonesia Cabang Jawa Timur yang disampaikan kepada Allah yaitu berupa pesan kehidupan yang lebih baik dengan hilangnya penyakit kanker di dunia ini dan pesan kematian beserta kehidupan setelahnya. Penderita kanker berharap agar tidak ada lagi penyakit kanker, sehingga tidak ada lagi individu yang merasakan kesusahan dan kesakitan karena penyakit kanker. Selain itu penderita kanker berharap agar kematian mendatanginya di saat yang sudah tepat, yaitu saat dirinya sudah benar- benar siap dengan bekal yang dapat membawanya pada surga.

Penderita kanker memanfaatkan ibadah dan aktivitas yang rutin dilakukan sehari-hari sebagai media komunikasi transendental. Ada dua media yang digunakan oleh penderita kanker dalam melakukan komunikasi transendental yaitu media yang hanya dirinya sendiri yang berperan dan media yang perannya bergantung pada dirinya sendiri dan individu lainnya. Mulai dari abngun tidur, penderita kanker melakukan ibadah sebagai media yang memanfaatkan peran dirinya sendiri. Namun dalam bergaul dengan orang lain, penderita kanker memanfaatkan peran individu lain untuk menyampaikan maksud dan tujuan komunikasi transendentalnya.

Model komunikasi transendental penderita kanker terjadi secara vertikal dan 
horizontal. Secara vertikal saat penderita kanker berkomunikasi dengan Allah tanpa perantara makhluk lain melalui ibadah. Sedangkan komunikasi transendental secara horizontal saat penderita kanker menyampaikan maksud dan tujuannya melalui kegiatan yang melibatkan individu lainnya, seperti sedekah

\section{Daftar Pustaka}

Abdul Baqi, Muhammad Fu'ad. 2005. Mutiara Hadits yang disepakati Bukhori dan Muslim (Al-Lu'lu' wal Marjan). Surabaya: PT. Bina Ilmu Offset.

Agustian, Ary Ginanjar. 2005. ESQ:The ESQ Way 165 (Berdasarkan 1 Ihsan 6 Rukun Iman dan 5 Rukun Islam). Jakarta: Arga.

Ali, H. Zaidin. 2010. Agama, Kesehatan dan Keperawatan. Jakarta: CV. Trans Info Media.

Al-Qur'an terjemah, Jakarta Timur: Pustaka Al-Mubin.

Ardianto, Elvinaro, Lukita Komala, and Siti Kartinah. 2007. Komunikasi Massa Suatu Pengantar, Revisi. Bandung : Sembiosa Rekatama Media.

Bachtiar, Edi. Shalat Sebagai Media Komunikasi Vertikal Transendental Jurnal Bimbingan Konseling Islam Vol. 5, No. 2 Desember 2014 (Jawa Tengah: STAIN Kudus

Berger, Artur Asa. 2004. Tanda-tanda Dalam Kebudayaan Kontemporer, trans

M. Dwi Mariyanto and Sunarto. Yogyakarta : Tiara Wacana.

Cahyo, Agus Nur. 2013. Bukti-Bukti Ilmiah Manfaat Ajaib Ibadah Seharihari. Jakarta: Sabil.
Djatmiko, Ario. 2010. "Kumpulan Materi, Sosialisasi Yayasan Kanker Indonesia Cabang Jawa Timur”.

Eckholm, Erik P. 1981. Masalah Kesehatan, Lingkungan sebagai Sumber Penyakit. Jakarta: PT Gramedia.

Elzaky Jamal. 2011. Buku Induk Mukjizat Kesehatan Ibadah. Jakarta: Zaman. Gawler, Ian. 1997. Anda Dapat Mengatasi Kanker. Jakarta: Pustaka Sinar Harapan.

Haryanto, Sindung. 2002. Spektrum Teori Sosial Dari Klasik Hingga Post Modern. Yogyakarta : Ar-Ruz Media.

Hoepoedio, R.S. 2010. “Kumpulan Naskah Tentang Masalah Kanker", II. Penanggulangan Kanker Terpadu.

Hoepoedio, R.S. 2010. “Kumpulan Naskah Tentang Masalah Kanker", III. Penanggulangan Kanker Terpadu (Naskah Ceramah).

Jamaluddin, Syakir. 2010. Kuliah Fiqih Ibadah. Yogyakarta: Surya Sarana Grafika.

Kadri. 2010. Religiusitas dan Konstruksi Komunikasi Transendental Tunanetra.

Mataram: IAIN Mataram.

Kriyantoro, Rachmat . 2006. Teknik Praktis Riset Komunikasi. Jakarta: Kencana. Koencoroningrat. 1981. Metode-Metode Penelitian Masyarakat. Jakarta: Gramedia Pustaka Utama.

Le Mone, Priscilla. 2015. Buku Ajar Keperawatan Medikal Beda. Jakarta: Volume 1 Edisi 5 EGC.

Mille, Matthew B. dan A. Michael Huberman. 1992. Analisis data Kualitatif, terj, Tjeptjep Rohendi Rohedi. Jakarta : UI Pers. 
Mudjiono, Yoyon. 2013. Ilmu Komunikasi. Surabaya: Jaudar press. Mulyana, Deddy. 2002. Metodologi Penelitian Kualitatif . Bandung : Remaja

Rosdakarya.

Mulyana, Deddy. 2001. Ilmu Komunikasi. Bandung: Remaja Rosdakarya

Mulyana, Deddy. dkk. 1990. Komunikasi Antar Pribadi . Bandung: PT Remaja Rosda Karya.

Mulyana, Deddy. 1990. Nuansa-Nuansa Komunikasi; Meneropong Politik dan Budaya Komunikasi Masyarakat Kontemporer. Remaja Rosdakarya: Bandung.

Muqaddim, Muhammad bin ahmad bin ismail. 2005. Limadza asshalat ( Mengapa Kita Harus Shalat), terj Abu Harun Husain Sunding. Jogjakarta: Media Hidayah, Oktober.

Moleong, Lexy J. 2002. Metodologi Penelitian Kualitatif, Cet. 13. Bandung: Remaja Rosdakarya.

Nazir, Moh. 1990. Metode Penelitian, Cet. IV. Jakarta: Ghalia Indonesia. Narbuko, Cholid dan Abu Achmadi. 1997. Metodologi Penelitian, Cet. 1. Jakarta: Bumi Aksara.

Rakhmat, Jalaluddin. 2009. Psikologi Komunikasi. Edisi Revisi. Bandung: Remaja Rosdakarya. 